\title{
Effects of hay quality on intake, growth path, body composition and muscle characteristics of Salers heifers
}

\author{
Thierry HoCH* ${ }^{a *}$, Catherine JURIE ${ }^{\mathrm{a}}$, Philippe PRADEL ${ }^{\mathrm{b}}$, \\ Isabelle CASSAR-MALEK ${ }^{\mathrm{a}}$, Roland JAILLER ${ }^{\mathrm{a}}$, Brigitte PICARD ${ }^{\mathrm{a}}$, \\ Jacques AGABRIEL ${ }^{\mathrm{a}}$

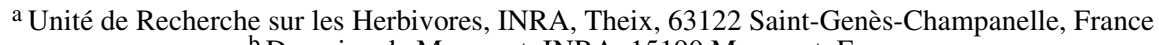 \\ ${ }^{\mathrm{b}}$ Domaine de Marcenat, INRA, 15190 Marcenat, France
}

(Received 14 June 2004; accepted 1 February 2005)

\begin{abstract}
A comparison between continuously (CG group, $\mathrm{n}=9$ ) and discontinuously (DG, $\mathrm{n}=$ 14) growing Salers heifers during a two year growth period after weaning was performed. Feed was available to all animals ad libitum throughout the experiment. Growth differences in the winter resulted from a different quality of the offered hay. In the summer, the animals were conducted indoors and offered the same good quality hay. Serial slaughter was carried out in order to estimate the evolution of body composition and muscle characteristics (fibre type and area, collagen) which may influence meat quality. This experimental scheme made it possible to simulate two types of nutritional environment (poor and rich) and to study their impact on intake, growth, body composition and muscle characteristics of the animals. DG heifers always underwent a summer compensatory growth, even though not complete, when compared with CG animals. The final slaughter was carried out at the same live weight, approximately $700 \mathrm{~kg}$. On average, DG heifers were therefore slaughtered

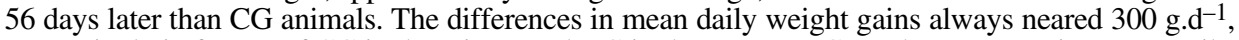
respectively in favour of CG in the winter and DG in the summer. Growth compensation was attributable to an increased intake (between +6 and $+7 \%$ ) in the summer and a tendency for a higher growth efficiency of DG animals. No significant major difference was detected between CG and DG body composition at the final slaughter at which final carcass was approximately $400 \mathrm{~kg}$ and total adipose tissue weight reached approximately $130 \mathrm{~kg}$ ( $21.5 \%$ of the empty body weight). Final muscle characteristics were not modified by growth type either. It was concluded that growth path can vary according to food availability, without affecting the characteristics of the finished carcasses at constant weight.
\end{abstract}

growth path / heifer / body composition / muscle characteristics / hay intake

\footnotetext{
* Corresponding author: hoch@ vet-nantes.fr

Present address: UMR ENV Nantes INRA Gestion de la Santé Animale, Atlanpole-Chantrerie, BP 40706, 44307 Nantes Cedex 03, France.
} 
Résumé - Effets de la qualité du foin sur l'ingestion, l'itinéraire de croissance, la composition corporelle et les caractéristiques musculaires de génisses Salers. Deux lots de génisses Salers conduites en croissance continue (lot $C G, n=9$ ) ou discontinue ( $D G, n=14$ ) ont été comparés pendant deux années de croissance post-sevrage. Pendant toute l'expérience, les animaux étaient alimentés à volonté. Les écarts hivernaux de croissance étaient dus à la distribution de foins de qualité distincte. En été, les génisses restaient à l'étable et recevaient un foin identique de bonne qualité. Les évolutions de la composition corporelle et des caractéristiques musculaires (type et surface des fibres, collagène) susceptibles d'influer sur la qualité de la viande, ont été estimées après des abattages en série. Ce schéma expérimental a permis de simuler deux types de milieu nutritionnel (pauvre et riche) et d'en étudier l'impact sur l'ingestion, la croissance, la composition corporelle et les caractéristiques musculaires des animaux. Le lot DG a systématiquement réalisé une croissance compensatrice estivale, bien qu'incomplète, par rapport au lot CG. Du fait d'un abattage final à même poids vif, environ $700 \mathrm{~kg}$, les animaux DG ont été abattus en moyenne 56 jours plus tard que les génisses CG. Les différences de gains de poids moyens valent toujours environ $300 \mathrm{~g} \cdot \mathrm{j}^{-1}$, en faveur respectivement de $\mathrm{CG}$ en hiver et de DG en été. La compensation était due à une ingestion accrue en été (entre +6 et $+7 \%$ ) et à une tendance pour une meilleure efficacité de la croissance des animaux DG. Aucune différence notable de composition corporelle n'a été observée entre lots après l'abattage final. Le poids des carcasses était alors légèrement inférieur à $400 \mathrm{~kg}$ et celui des tissus adipeux totaux atteignait environ $130 \mathrm{~kg}(21,5 \%$ du poids vif vide). Le type de croissance n'a pas non plus influé sur les caractéristiques musculaires finales. En conclusion, l'itinéraire de croissance de l'animal peut varier en fonction de la disponibilité alimentaire, sans modifier les caractéristiques des carcasses finies à poids constant.

itinéraire de croissance / génisse / composition corporelle / caractéristiques musculaires / ingestion de foin

\section{INTRODUCTION}

The quantity and quality of the feed given to beef cattle determines their growth path. In mountainous areas in particular, the quality of the hay offered in the winter may be highly variable, resulting in variable growth rates. Periods of poor food supply may be followed by periods of adequate food supply, especially at pasture. During these latter periods, previously restricted animals may compensate for all or part of the weight difference, compared with continuously fullfed cattle. Compensatory growth in ruminants is a well-known phenomenon and has been described in detail in the reviews of O'Donovan [31] and Ryan [40], among others. According to these authors, compensatory growth can be attributed to different physiological and metabolic processes. After a restriction period, intake by previously restricted animals increases at the beginning of the compensation period. Furthermore, energetic efficiency is higher for compensating animals than for animals who were not previously restricted. Lastly, the gain of compensating animals is richer in protein, associated with water, therefore resulting in a greater weight gain per unit of energy deposition. Most experiments on compensatory growth in beef cattle do not last much more than a year. In these experiments, nutritional restriction is achieved by reducing the food supply, and the effect of compensation on muscle characteristics (fibre type and area, collagen), which influence meat quality [14], are rarely measured.

The aim of this study was to compare two growth paths of heifers, for a 2-year growth period post weaning. One growth path resulted from a continuous supply of good feed and represented regular growth. The other was obtained by alternating phases with good and poor quality feed. Generating different growth paths by varying the quality of hay made it possible to (i) study the evolution of intake for each growth path, and (ii) simulate the influence of two different nutritional environments on the growth, the body composition and the muscle characteristics of the animals. 
Table I. Average characteristics of the forage given to the Discontinuous (DG) and Continuous (CG) Group for the different periods. Units for energy and protein content of hays refer to the French system for energy and protein allowance [21].

\begin{tabular}{lcccccc}
\hline Period & \multicolumn{2}{c}{ 1st winter } & 1st summer & 2nd winter & 2nd summer \\
\hline Group & CG & DG & CG and DG & CG & DG & CG and DG \\
\hline Dry matter content (DM) $\left(\mathrm{g} \cdot \mathrm{kg}^{-1}\right.$ fresh matter) & 872 & 882 & 843 & 871 & 861 & 860 \\
Organic matter content $(\mathrm{OM})\left(\mathrm{g} \cdot \mathrm{kg}^{-1} \mathrm{DM}\right)$ & 909 & 929 & 900 & 904 & 921 & 907 \\
OM digestibility $(\%)$ & 63.8 & 58.6 & 68.1 & 67.9 & 53.8 & 69.0 \\
Energy content (UFL $\left.\mathrm{kg}^{-1} \mathrm{DM}\right)$ & 0.74 & 0.65 & 0.80 & 0.80 & 0.59 & 0.83 \\
Protein content (PDI in $\left.\mathrm{g} \cdot \mathrm{kg}^{-1} \mathrm{DM}\right)$ & 80 & 50 & 89 & 84 & 56 & 96 \\
\hline
\end{tabular}

\section{MATERIALS AND METHODS}

\subsection{Experimental design}

This study was carried out at the experimental farm of Marcenat (Cantal, France). After weaning, at approximately 8 months of age and an average weight of $302.1 \mathrm{~kg}$ $($ s.e. $=5.7)$, twenty-three Salers (hardy breed) heifers were assigned to two groups: a discontinuous growth group (DG, 14 animals) alternating periods of low quality (winters) and good quality (summers) feed and a continuous growth group (CG, 9 animals) which continuously received good quality feed. The growth of both groups was studied over two years.

The heifers were permanently housed and individual intake was continuously measured. Hay was available ad libitum throughout the experimental period. Table I summarises the characteristics of the hay offered to each group. Organic matter digestibility (OMD) of the hay, measured on sheep, varied from $53.7 \%$ to $69.0 \%$. The net energy content of the hay was estimated from crude protein and crude fibre contents, as well as OMD as described by INRA [20]. Beet pulp $(0.5 \mathrm{~kg})$ was also offered to $C G$ animals during the first winter. Soybean meal $(0.2 \mathrm{~kg})$ was offered every day to all the animals in order to guarantee a minimum level of protein in the diet. The housing differed between feeding periods: the animals were tied in the winter and loose- housed in the summer. This allowed the animals to get exercise in the summer. This helped to simulate the walking of the animals when they graze, even though the energy expenditure is inevitably smaller than it could be at pasture.

\subsection{Measurements}

The comparison between both groups was based on measures of animal performance, body composition and muscle characteristics. The relation between growth path and hormonal status of the animals has also been studied, in order to explain the physiological mechanisms involved.

Full body weight (FBW) was measured weekly. Intake was measured daily, with a weekly estimation of hay dry matter content offered and refused. Dry matter intake (DMI, in $\mathrm{kg} \mathrm{DM}$ ) was thus calculated by multiplying weekly averaged intakes by the dry matter content. In order to allow for a comparison between the two groups, DMI values were divided by metabolic weight $\left(\mathrm{FBW}^{0.75}\right)$, thus leading to standardised DMI (SDMI). Ad libitum feeding permitted estimates of the individual intake capacity (IC, in Fill Unit, FU, [22]) during the whole experiment by multiplying the DMI of the animals by the Fill Unit value (in FU per kg DM) of the given hay. The total energy intake by the animals of both groups over the whole experiment was calculated by multiplying DMI by the energy content of 
the hay and by adding the energy value of the offered concentrate.

Hormonal status was estimated on blood samples collected by venipuncture of the jugular vein of heifers, at the end of different periods: first winter (9 CG and $11 \mathrm{DG}$ ); first summer (9CG and $11 \mathrm{DG}$ ); 2nd winter (5 CG and $7 \mathrm{DG}$ ); 2nd summer (5 CG and $4 \mathrm{DG}$ ). It has previously been shown [8] that only thyroid status was modified in response to the discontinuous growth path. Concentrations of thyroid hormones (T4: thyroxine and T3: triiodothyronine) were determined as previously described by Cassar-Malek et al. [8].

The body composition of the animals was estimated throughout the experiment by indirect or direct measurements. In vivo estimations consisted of the monthly measurement of body condition score (BCS, scale 0 to 5, [1]), and of the assessment of adipose cell size [36] measured at the end of the winter and summer periods. In order to estimate chemical or tissue composition directly, serial slaughter was carried out at the end of the winter and summer periods for DG, and only after the summer periods for CG. The extra DG slaughter was to estimate the influence of compensatory growth on the evolution of body composition. Slaughtering animals from each group at the end of each summer period allowed DG and $\mathrm{CG}$ to be directly compared at these times. The distribution of slaughtering was 3 animals at the end of each winter and 4 at the end of each summer for DG, and 4 heifers at the end of the first summer and 5 at the end of the 2 nd summer for CG. At the end of the experiment, the animals were slaughtered at the same weight for CG and DG, which inevitably resulted in a difference in slaughter age. After slaughter, each component of the animal was weighed, in order to estimate tissue composition. Half of the carcass was dissected in order to determine the relative proportion of bone, muscle and adipose tissue. In order to estimate the chemical composition, the following body components were ground, after grouping some of them: reticulo-rumen, large and small intestine, liver, kidneyspleen-pancreas, hide, muscle (estimated on the 6th rib), adipose tissue in carcass and non-carcass, and the remaining of non-carcass organs (heart, lung, genitals, udder taken together...). After grinding, four samples of each component were frozen $\left(-20^{\circ} \mathrm{C}\right)$ for further analyses of dry matter percentage, protein and lipid contents. Kjeldahl analyses were used to estimate nitrogen, and further protein content of the samples. A calorimetric analysis was carried out to determine the energy content of each sample. Lipid content was thus indirectly estimated, since total energy content was the sum of the energy fixed by proteins and lipids (Prot and Lip, in kg) [20]:

\section{Energy Content $($ in MJ $)=22.94 \times$ Prot + $39.23 \times$ Lip}

The initial body composition of the heifers was estimated from allometry equations derived from Geay et al. [13], and further used by INRA [21]. These equations gave for an initial FBW of $302.1 \mathrm{~kg}$ an estimated empty body weight (EBW) of $252.9 \mathrm{~kg}$. Initial chemical composition could not be determined separately for the carcass and the non-carcass tissues and was estimated as $46.5 \mathrm{~kg}$ of proteins and $33.1 \mathrm{~kg}$ of lipids (respectively 18.4 and $13.1 \%$ of EBW). From Robelin and Geay [37], adipose tissue weight can be deduced from lipid content, giving an estimated value of $30.0 \mathrm{~kg}$ of adipose tissue in EBW, which corresponds to $11.9 \%$ of EBW.

Considering that initial EBW and chemical composition were the same for the two groups, the changing composition of the gain was estimated. When a decrease in total lipid content was observed, the proportion of lipid in the gain was set to 0 .

Muscle characteristics were estimated on samples from Triceps brachii (TB) collected after slaughter. These were frozen in liquid nitrogen, and stored at $-80{ }^{\circ} \mathrm{C}$ until they were analysed. Mean fibre area and proportions of different fibre types were 
determined by histochemistry. Mean fibre area was measured on $10 \mu \mathrm{m}$ thick azorubinstained cryostat transverse sections. The fibre types were identified according to ATPase and succinate dehydrogenase reactions and classified according to Peter et al. [33] as slow oxidative (SO), fast oxidative glycolytic (FOG) and fast glycolytic (FG). Lactate dehydrogenase (LDH: EC 1.1.1.27.) and isocitrate dehydrogenase (ICDH: EC 1.1.1.42) activities, representative respectively of glycolytic and oxidative metabolism, were determined on these muscle samples as previously described by Jurie et al. [23]. LDH activity was measured by following the disappearance of nicotinamide adenine dinucleotide, reduced form (NADH), and ICDH activity was measured by following the reduction of nicotinamide adenine dinucleotide phosphate (NADP). Specific activity was expressed in $\mu \mathrm{mol}$ of substrate liberated per min and per $g$ of wet tissue weight. Total collagen content was determined as described by Listrat et al. [27]. The data were expressed in $\mu \mathrm{g}$ of hydroxyproline (OH-prol) per mg of dry matter (DM).

\subsection{Statistical analyses}

Data on animal weight, feed intake and thyroid hormones were analysed, using the Proc Mixed procedure of SAS (SAS Inst., Inc., Cary, NC). This procedure assumes that repeated observations on the same animal are likely to be related. It also allowed individual variability to be considered during repeated measurements. It is appropriate for the analysis of unbalanced data.

For FBW analysis, the group (CG and DG), the period (winter and summer of each year of the experiment) and time (regressor) were considered as fixed factors in the model, together with their interactions. The mixed model considers individual variability on the intercept as well as on the slope of the regression of weight against time, as in Robert-Granié et al. [39]. A multiple comparison procedure, using Proc GLM of SAS and Tukey-Kramer tests, was performed to compare least-squares means of estimated individual average daily gains (ADG) between groups and periods.

SDMI and thyroid hormone data were also analysed using a mixed model. In both cases, the group, the period and the group $\times$ period interaction represented the fixed effects. Similarly as in Littell et al. [28], two types of covariance structures were applied to these data: (i) random intercept, for individual variability, and first-order auto-regressive process, for time correlation between measurements, for feed intake data, and (ii) compound symmetry structure, for thyroid hormone data, on account of a large time lag between measurements. A comparison between least-squares means with the TukeyKramer test was also performed. The evolution of the body composition and of muscle characteristics with age were studied and analysed by a hierarchical analysis of variance (age in each group) using Proc GLM of SAS. Pairwise comparisons between mean energy intake by both groups during each period and between body composition of DG and CG at the end of the summer periods were carried out by comparing leastsquares means given by Proc GLM (t tests). Data representing proportions were transformed using $\operatorname{Arcsin}(\sqrt{ })$ transformation.

\section{RESULTS}

\subsection{Weight and weight gains}

Figure 1 summarises the evolution of mean FBW per group. Final weight at slaughter was 698.4 and $700.2 \mathrm{~kg}$ for CG and DG respectively. DG heifer weights decreased sharply at the beginning of each summer period, due to a reduction in gut contents on moving to a higher digestibility diet. The weight difference between CG and DG was $56.7 \mathrm{~kg}$ at the end of the first winter. This decreased to $24.7 \mathrm{~kg}$ by the end of the first summer period, but increased again during the second winter to $72.2 \mathrm{~kg}$. At the end of the experiment, the slaughter date of DG was 56 days later than for CG. Final slaughter for CG and DG corresponded to 32 and 


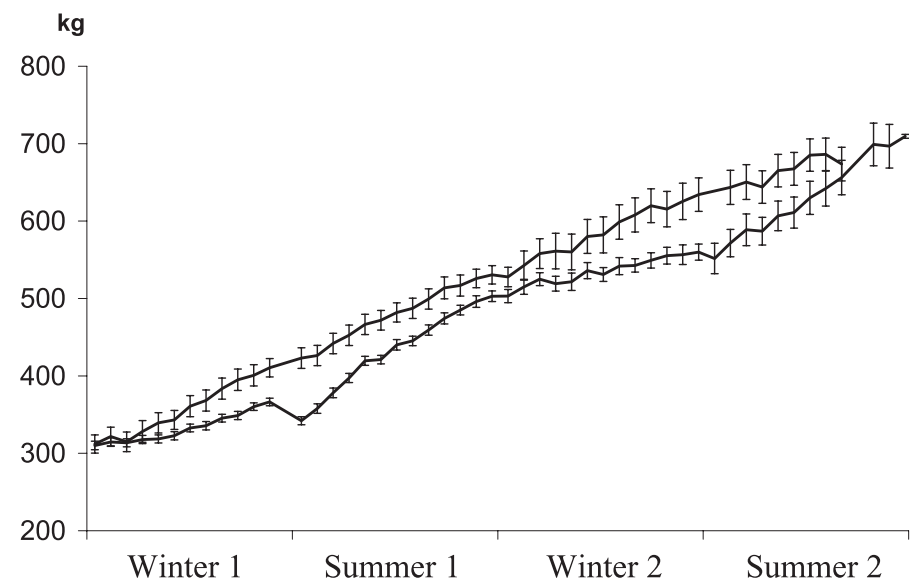

Figure 1. Evolution of Full Body Weight (in $\mathrm{kg}$ ) of continuously (thick line) or discontinuously (thin line) growing heifers, with standard error. For legibility, a two week step is used for data plotting.

34 months of age respectively. At the time of final slaughter for CG, the weight difference between the two groups was $37.7 \mathrm{~kg}$.

Statistical analyses showed that the interaction of slope between the time of the measurement and the group $\times$ period interaction acted significantly on animal weight $(P<0.001)$. This indicated that ADG varied significantly between groups and feeding periods. Table II shows the least-squares means for ADG per group and period. From this table and from Figure 1, it can be concluded that the growth of CG heifers was quite constant throughout the experiment, although it slowed somewhat during the second year of growth as the animals approached maturity. On the contrary, ADG of heifers in DG differed significantly between the winter and summer periods, with a difference of about $600 \mathrm{~g} \cdot \mathrm{d}^{-1}$ between these two periods. Mean ADG over the whole experiment was 595 and $551 \mathrm{~g} \cdot \mathrm{d}^{-1}$ for CG and DG respectively.

\subsection{Feed and energy intake}

Daily DMI did not show the same pattern of evolution for CG and DG throughout the experiment. Figure 2 indicates an increased DMI for the CG group at the beginning of the experiment before it reached a plateau as the animals approached maturity. The DMI of DG heifers differed significantly between the winter and summer. Summer values were clearly higher than the winter ones. However, winter feed intake was

Table II. Average (Lsmeans \pm standard error) daily live weight gain $\left(\mathrm{kg} \cdot \mathrm{d}^{-1}\right)$ for the Discontinuous (DG) and Continuous (CG) Groups, during the different periods of the experiment. Between the groups and periods, lsmeans with different superscripts are significantly different $(P<0.05)$ according to Tukey-Kramer grouping.

\begin{tabular}{ccccc}
\hline & 1 st winter & 1st summer & 2nd winter & 2nd summer \\
\hline CG & $0.686^{\mathrm{a}}$ & $0.698^{\mathrm{a}}$ & $0.605^{\mathrm{a}}$ & $0.558^{\mathrm{a}}$ \\
& \pm 0.032 & \pm 0.032 & \pm 0.042 & \pm 0.042 \\
DG & $0.386^{\mathrm{b}}$ & $0.975^{\mathrm{c}}$ & $0.315^{\mathrm{b}}$ & $0.884^{\mathrm{c}}$ \\
& \pm 0.025 & \pm 0.025 & \pm 0.036 & \pm 0.047 \\
\hline
\end{tabular}




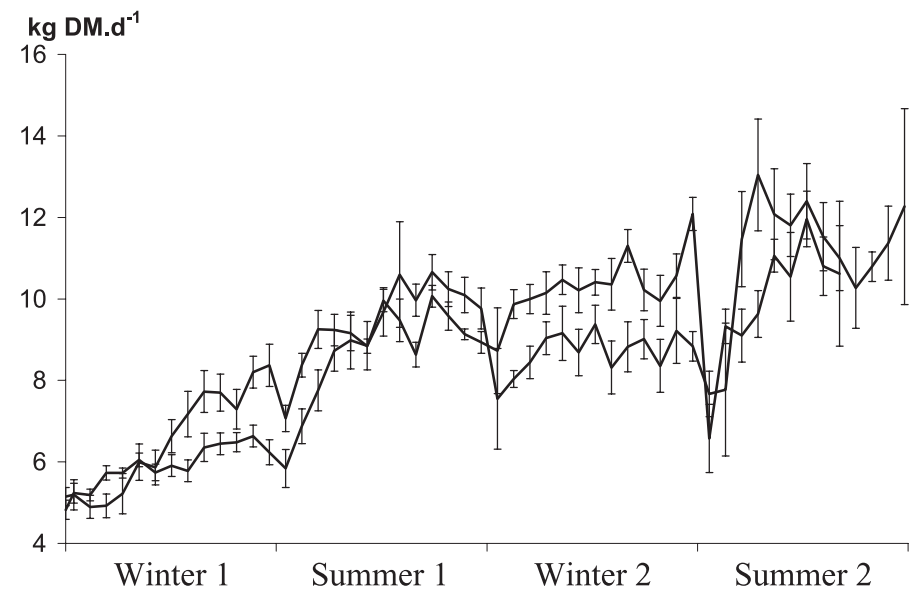

Figure 2. Evolution of daily dry matter intake (in $\mathrm{kg} . \mathrm{d}^{-1}$ ) of continuously (thick line) or discontinuously (thin line) growing heifers, with standard error. For legibility, a two week step is used for data plotting.

higher the second year of the experiment than the first one. For both groups, DMI values decreased at the beginning of each summer period, during the first three weeks.

The application of a mixed model to the intake standardised variable SDMI denoted the significant influence of individual variability on the intercept, and of the correlation between measurements repeated on each animal, through an auto-regressive process. As far as fixed effects are concerned, neither the interaction between group and period nor the group were found to have a significant effect on SDMI. A multiple comparison of SDMI between periods in each group was carried out (Tab. III). It demonstrated that intake in the first summer period was significantly higher than during the first winter. A small and not significant difference was observed between the winter and the summer of the second year of the experiment. In summary, SDMI of CG decreased from the first summer to the end of the experiment, whereas alternating phases of high and low intake were observed for DG.

With respect to net energy intake, pairwise comparisons showed a significantly higher energy intake for CG than for DG during the winter periods (t tests: $P<0.05$ for the first winter, $P<0.001$ for the second one). The least-squares means, for daily energy intake were 5.53 and $4.67 \mathrm{UFL} \cdot \mathrm{d}^{-1}$ for $\mathrm{CG}$ and $\mathrm{DG}$ respectively during the first

Table III. Average (Lsmeans \pm standard error) daily dry matter intake, standardised by metabolic weight (in $\mathrm{kg} \cdot \mathrm{d}^{-1}$ for $100 \mathrm{~kg}^{0.75}$ ), for Discontinuous (DG) and Continuous (CG) Groups, during the different periods of the experiment. Between periods, lsmeans with different superscripts are significantly different $(P<0.05)$ according to Tukey-Kramer grouping.

\begin{tabular}{lcccc}
\hline & 1st winter & 1st summer & 2nd winter & 2nd summer \\
\hline CG & $7.768^{\mathrm{a}}$ & $8.718^{\mathrm{b}}$ & $8.006^{\mathrm{ab}}$ & $7.695^{\mathrm{ab}}$ \\
& \pm 0.293 & \pm 0.297 & \pm 0.321 & \pm 0.401 \\
DG & $7.637^{\mathrm{a}}$ & $9.281^{\mathrm{b}}$ & $8.030^{\mathrm{a}}$ & $8.286^{\mathrm{ab}}$ \\
& \pm 0.235 & \pm 0.259 & \pm 0.274 & \pm 0.357 \\
\hline
\end{tabular}



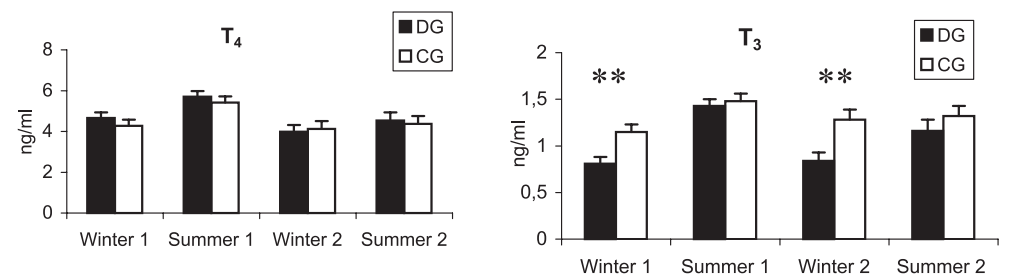

Figure 3. Thyroxine (T4) and Triiodothyronine (T3) plasma concentrations for the discontinuous group (DG) and continuous group (CG) during the different periods of the experiment, with standard error. ${ }^{* *}: P<0.01$ in the comparison between CG and DG.

winter. The corresponding values for the second winter were 7.89 and $5.58 \mathrm{UFL} \cdot \mathrm{d}^{-1}$, respectively. In the summer, energy intake differed between periods. It was still higher for CG than for DG for the first summer period $\left(6.72 \cdot \mathrm{d}^{-1}\right.$ vs. $\left.5.98 \mathrm{UFL} \cdot \mathrm{d}^{-1}, P<0.05\right)$, whereas no difference was observed for the last summer period $\left(\mathrm{CG}\right.$ : $9.10 \mathrm{UFL} \cdot \mathrm{d}^{-1}$, DG: $\left.8.22 \mathrm{UFL} \cdot \mathrm{d}^{-1}, P=0.14\right)$. The energy intake over the whole experimental period by the remaining animals was estimated at 4510 UFL for animals in DG and 4905 UFL for CG. This difference $(8 \%)$ between the groups tended towards significance $(P<0.10)$.

The protein to energy ratio of the diet never fell below $80 \mathrm{~g}$ PDI.UFL ${ }^{-1}$ for DG animals, which suggested that the lower growth rates were a consequence of energy, rather than protein supply.

\subsection{Hormonal status}

Only the period had a significant effect $(P<0.001)$ on T4 concentrations, whereas the group $(P<0.01)$ and the period $(P<$ $0.001)$ acted significantly on T3 concentrations. The effects of nutritional restriction and re-feeding on plasma concentrations of total T4 and T3 are presented in Figure 3. Circulating concentrations of $\mathrm{T} 4$ remained unaltered during the different periods. Compared with the CG group, plasma T3 concentrations were lower in the DG group on the first and second winters $(P<0.01)$. T3 concentrations did not differ between DG and CG groups on the first and second summers.

\subsection{Body composition}

\subsubsection{In vivo measurements}

From an initial mean BCS of 2.1, BCS of DG decreased to 1.78 at the end of the first winter and significantly differed from BCS of CG at $2.77(P<0.001)$. At the end of the first year, the mean value for $C G$ (3.37) was still significantly higher $(P<0.05)$ than that of DG (2.87). The two values diverged thereafter during the second winter (DG: 2.73 , CG: 4.43, $P<0.001$ ). However, at final slaughter, BCS did not differ between the two groups and was 4.25 and 4.07 for CG and DG respectively.

The initial value of adipose cell size diameter was $56.3 \mu \mathrm{m}$. After the first winter, a significant difference $(P<0.01)$ was measured between adipose cell size of DG $(46.8 \mu \mathrm{m})$ and $\mathrm{CG}(61.9 \mu \mathrm{m})$. However, no significant difference was encountered between the two groups at the end of the other winter or summer periods. Although not significant, a small difference was still observed at the end of the first summer period (101.1 $\mu \mathrm{m}$ for CG vs. $87.9 \mu \mathrm{m}$ for DG). Average adipose cell diameter decreased for both groups during the second winter and reached 75.0 and $78.3 \mu \mathrm{m}$ respectively, for CG and DG. At final slaughter, average values still tended to be lower for CG $(91.2 \mu \mathrm{m})$ than for DG $(116.5 \mu \mathrm{m})$. Associated standard deviations, particularly at the end of summer periods, were high. Values of 23.6 and 23.2 $\mu \mathrm{m}$ for $\mathrm{CG}$ and 

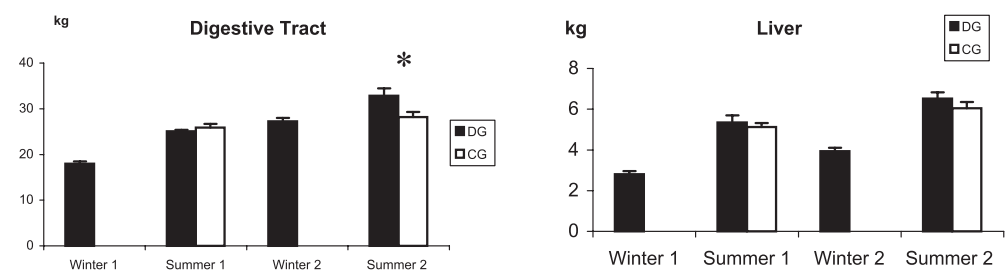

Figure 4. Digestive Tract (DT), and liver weights for the discontinuous group (DG) and continuous group $(\mathrm{CG})$ during the different periods of the experiment, with standard error. *: $P<0.05$ in the comparison between CG and DG.

DG animals respectively were observed at final slaughter.

\subsubsection{Tissue and body chemical composition}

\subsubsection{Tissue composition (Tab. IV)}

Both EBW and carcass weight increased continuously throughout the experiment. For DG, the increase in EBW was $124.0 \mathrm{~kg}$ for the first and $156.2 \mathrm{~kg}$ for the second summer period. Gains were lower during the winter periods and similar between them: $29.2 \mathrm{~kg}$ (with an initial EBW estimation of $252.9 \mathrm{~kg}$ ) and $29.7 \mathrm{~kg}$ during the first and the second winter respectively. During the second winter period, the EBW gain was mainly due to an increase in muscle weight, which increased from 170.3 to $193.9 \mathrm{~kg}$. On the contrary, total adipose tissue decreased slightly during the first winter from 29.9 (estimated) to $28.4 \mathrm{~kg}$ (measured). The decrease in adipose tissue during the second winter period was greater (from 61.6 to $51.3 \mathrm{~kg}$ ). Calculated as the difference between EBW and carcass weight, non-carcass weight increased slightly $(+3.9 \mathrm{~kg})$ during the same period. Among non-carcass tissues, the weight of the digestive tract increased throughout the experiment (Fig. 4). However, visceral organs, like the liver, were more affected by low quality feeding.

As far as the proportions of the different tissues are concerned, the proportion of adipose tissue in EBW (PAT) increased significantly with age $(P<0.001)$. Considering both groups together, PAT varied from the initial estimation of $10.9 \%$ to $21.5 \%$ at final

Table IV. Average (Means \pm standard error, in kg) Empty Body Weight (EBW), Carcass, Muscle and Adipose Tissue (AT) weight for Discontinuous (DG) and Continuous (CG) Groups, at the end of the different periods of the experiment. Statistical significance $(\alpha=0.05)$ estimated with Student t-tests between CG and DG measurements after the summer periods.

\begin{tabular}{|c|c|c|c|c|c|c|c|c|}
\hline & \multirow{2}{*}{$\frac{1 \text { st winter }}{\text { DG }}$} & \multicolumn{2}{|c|}{ 1st summer } & \multirow{2}{*}{$\begin{array}{c}\text { Statistical } \\
\text {-significance }\end{array}$} & \multirow{2}{*}{$\frac{2 \text { nd winter }}{\text { DG }}$} & \multicolumn{2}{|c|}{ 2nd summer } & \multirow{2}{*}{$\begin{array}{r}\text { Statistical } \\
\text { significance }\end{array}$} \\
\hline & & DG & $\mathrm{CG}$ & & & DG & $\mathrm{CG}$ & \\
\hline EBW & $282.0 \pm 3.0$ & $406.0 \pm 10.5$ & $443.7 \pm 13.8$ & $*$ & $435.7 \pm 2.4$ & $591.9 \pm 21.9$ & $603.6 \pm 17.6$ & NS \\
\hline $\begin{array}{l}\text { Carcass } \\
\text { Weight }\end{array}$ & $172.3 \pm 4.0$ & $259.2 \pm 6.2$ & $285.9 \pm 10.8$ & $*$ & $285.0 \pm 4.3$ & $387.0 \pm 14.0$ & $403.4 \pm 17.6$ & NS \\
\hline $\begin{array}{l}\text { Muscle } \\
\text { Weight }\end{array}$ & $116.2 \pm 3.4$ & $170.3 \pm 4.5$ & $190.4 \pm 6.6$ & $*$ & $193.9 \pm 5.0$ & $241.6 \pm 13.0$ & $245.4 \pm 7.0$ & NS \\
\hline $\begin{array}{l}\text { AT } \\
\text { Weight }\end{array}$ & $28.4 \pm 1.1$ & $61.6 \pm 1.8$ & $68.9 \pm 4.8$ & NS & $53.1 \pm 0.2$ & $127.2 \pm 6.9$ & $129.8 \pm 11.7$ & NS \\
\hline
\end{tabular}




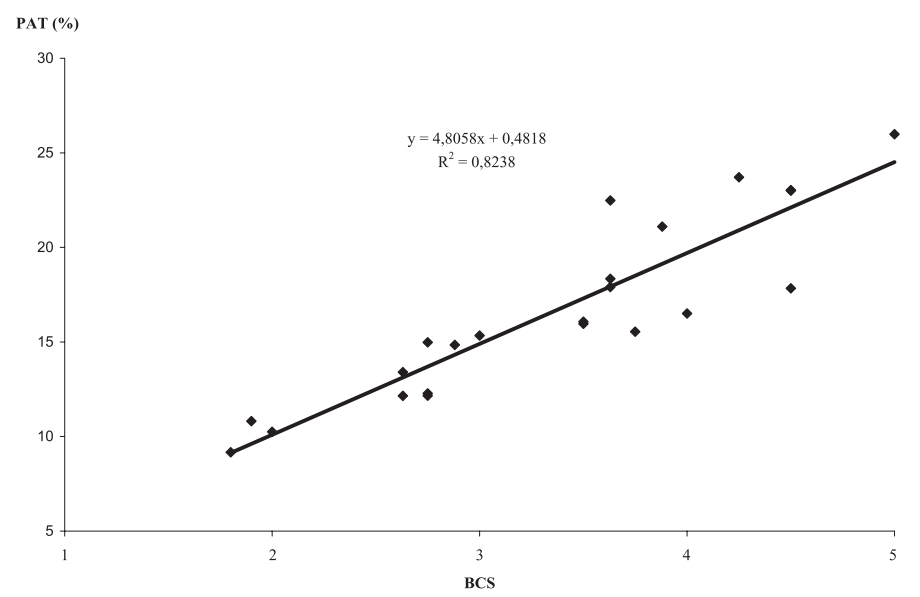

Figure 5. Relation between the Proportion of Adipose Tissue (PAT) in Full Body Weight (in \%) and Body Condition Score (BCS, No Unit).

slaughter. The proportion of adipose tissue in the carcass also increased significantly with age $(P<0.001)$. Unlike the proportions of adipose tissues, the proportion of muscle and bone in the carcass decreased significantly $(P<0.01$ and $P<0.001$, respectively). For both groups, carcass yield, calculated by the ratio carcass weight/EBW, increased with age $(P<0.001)$. It varied from 0.644 to 0.668 for $\mathrm{CG}$ and from 0.638 to 0.654 for DG during the second year of the experiment.

The comparison of body composition revealed that EBW $(+37.7 \mathrm{~kg})$, carcass weight $(+26.7 \mathrm{~kg})$ and muscle weight $(+20.1 \mathrm{~kg})$ were significantly higher in CG than in DG $(P<0.05$ with a one-tailed test $)$ at the end of the first summer. On the contrary, adipose tissue weight, as well as the proportion of the tissues in the body and carcass did not differ between CG and DG. At the end of the experiment, few significant differences remained between the two groups for tissue weights and proportions. The digestive tract was significantly heavier $(P<0.05)$ in DG than in CG heifers (Fig. 4). A slight difference in carcass yields $(P<0.10)$ was thus evident, with a higher value for $C G$ (0.668) than for DG (0.654).
PAT and BCS of animals of both groups before their slaughter were linearly related (Fig. 5). From this relationship, each point of BCS corresponded to $4.8 \%$ of adipose tissue in EBW. This demonstrates that BCS could be a valuable estimator of the fat content of the growing heifers, even though a large variability in the PAT was observed for high BCS.

\subsubsection{Chemical composition}

The estimated chemical composition of the animals followed approximately their tissue composition. For instance, a good correlation was found between total lipid content (Lip, in $\mathrm{kg}$ ) and adipose tissue weight (ATW, in $\mathrm{kg}$ ):

$$
\text { Lip }=1.277 \mathrm{ATW} \quad \mathrm{R}^{2}=0.998
$$

Protein contents of DG heifers increased during winter periods $(+10.6$ and $+2.6 \mathrm{~kg}$, successively). However, the evolution of protein contents for this group differed between carcass and non-carcass parts (Tab. V). Low quality feed during the second winter resulted in a loss of non-carcass protein content $(-0.9 \mathrm{~kg})$ whereas a slight 
Table V. Average (Means \pm standard error, in $\mathrm{kg}$ ) protein and lipid contents in carcass and non-carcass tissues for Discontinuous (DG) and Continuous (CG) Groups, at the end of the different periods of the experiment. No significant difference $(\alpha=0.05)$ was found with Student t-tests between CG and DG measurements after the summer periods.

\begin{tabular}{lccccccc}
\hline & & 1st winter & \multicolumn{2}{c}{ 1st summer } & \multicolumn{2}{c}{ 2nd winter } & \multicolumn{2}{c}{ 2nd summer } \\
\cline { 3 - 8 } & & DG & DG & CG & DG & DG & CG \\
\hline \multirow{2}{*}{ Protein } & Carcass & $34.4 \pm 0.9$ & $49.9 \pm 1.6$ & $54.7 \pm 2.9$ & $53.4 \pm 1.0$ & $63.5 \pm 3.2$ & $68.0 \pm 3.5$ \\
& Non-Carcass & $22.4 \pm 0.6$ & $25.7 \pm 0.7$ & $26.6 \pm 0.9$ & $24.8 \pm 1.7$ & $29.8 \pm 0.8$ & $29.3 \pm 1.5$ \\
\multirow{2}{*}{ Lipid } & Carcass & $20.4 \pm 1.0$ & $45.7 \pm 0.8$ & $50.8 \pm 3.4$ & $43.0 \pm 0.8$ & $102.7 \pm 6.5$ & $105.4 \pm 10.6$ \\
& Non-Carcass & $15.1 \pm 1.8$ & $33.3 \pm 1.9$ & $37.2 \pm 3.7$ & $31.6 \pm 1.9$ & $60.6 \pm 3.1$ & $57.9 \pm 6.0$ \\
\hline
\end{tabular}

gain of carcass content $(+3.5 \mathrm{~kg})$ was observed. The increase in carcass protein content was greater during the first summer than during the second, whereas protein in non-carcass tissues increased similarly during the same periods.

Table V underlines the similar evolution of lipid content in carcass or non-carcass tissues of DG animals. Lipid content increased during summer periods, especially in the carcass during the second period (from 43.0 to $102.7 \mathrm{~kg}$ ). The difference in total lipid content between the end and the beginning of the first winter period was estimated at $+2.5 \mathrm{~kg}$. During the second winter period, the lipid content decreased in both body components $(-2.7$ and $-1.7 \mathrm{~kg}$ in carcass and non-carcass tissues, respectively).

The lipid and protein proportions in carcass or non-carcass tissues evolved in opposite directions. Protein proportions diminished significantly with the age of the animals $(P<0.001)$, unlike lipid proportions, which continuously increased $(P<0.001)$.

The comparison between groups at the end of each summer period did not show any significant difference in either quantities or proportions of most chemical components in EBW. Only the reticulo-rumen of DG heifers was shown to contain less lipids than that of CG animals, at the end of the first summer $(P<0.05)$. At final slaughter, the animals had the same chemical composition.

The evolution of the gain composition (Tab. VI) showed for DG heifers alternating
Table VI. Estimation of the chemical composition of the gain (in \%), for Discontinuous (DG) and Continuous (CG) Groups, during the different periods of the experiment. LFM corresponds to Lipid Free Matter.

\begin{tabular}{lccc}
\hline Group & Period & LFM (in \%) & Lipid (in \%) \\
\hline DG & 1st winter & 92.0 & 8.0 \\
& 1st summer & 64.9 & 35.1 \\
& 2nd winter & 100.0 & 0.0 \\
& 2nd summer & 43.2 & 56.8 \\
CG & 1st year & 71.5 & 28.5 \\
& 2nd year & 52.9 & 47.1 \\
\hline
\end{tabular}

periods where the gain was low in lipids (winter) and where it was high in lipids (summer). The proportion of lipid in summer gains of DG heifers tended to be higher than that for $\mathrm{CG}$ animals estimated over the whole year. For both groups, the gain became richer in lipids as the animals grew: after the second summer than after the first for DG, and after the second year for CG.

\subsection{Muscle characteristics}

The mean fibre area significantly increased by 30 and $40 \%$ respectively in $\mathrm{DG}(P<0.05)$ and CG $(P<0.01)$ between 22 (end of first year) and 32 or 34 months of age (Fig. 6). Moreover, the mean fibre area increased by $112 \%$ between 16 and 34 months in DG $(P<0.001)$. However, the results did not show any significant effect of age in the proportions of the different fibre types and 


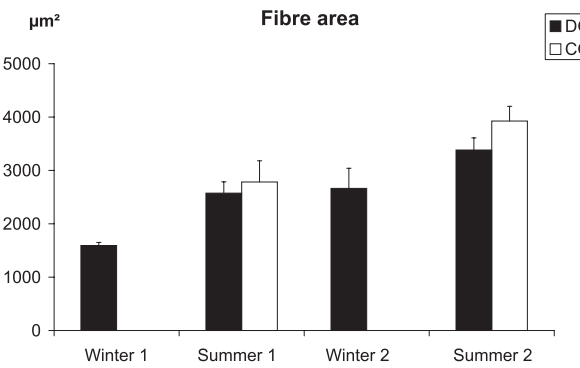

Figure 6. Mean fibre area of Triceps brachii muscle for the discontinuous group (DG) and continuous group (CG) during the different periods of the experiment, with a standard error.

LDH and ICDH activities between 16 (end of first winter) and 34 months for DG and between 22 and 32 months for CG (results not shown). During the second winter, the mean fibre area did not increase in DG (Fig. 6). At the end of the first and second summers, no significant differences were detected in the mean area of fibres between DG and CG, even though a numerically smaller size for DG than for CG (respectively 3383 and $3926 \mu^{2}$ ) was noted after the final slaughter. No significant differences were detected in SO, FOG and FG fibre type proportions, nor in $\mathrm{LDH}$ and ICDH activities. Thus, metabolic and contractile properties of TB muscle were not different between DG and CG groups at the end of the first and second summers (Tab. VII). Total collagen content differed significantly between periods. It decreased during the second summer $(P<0.01)$, particularly for CG (Tab. VII).

\section{DISCUSSION}

\subsection{Evolution with age}

\subsubsection{Weight and body composition}

This study described the growth of Salers heifers from 300 to $700 \mathrm{~kg}$ of live weight. Considering continuously growing animals, ad libitum feeding with a good quality hay resulted in a quasi-linear growth curve, with a slight decrease in daily gain as the animals approached maturity. As has been known for a long time [38], the proportion of lipids in the gain increased and the proportions of protein and ash decreased with increasing body weight.

Table VII. Triceps brachii muscle characteristics for the discontinuous group (DG) and continuous group (CG) at the end of first and second summers.

\begin{tabular}{|c|c|c|c|c|c|}
\hline \multirow{2}{*}{$\begin{array}{l}\text { Period } \\
\text { Group }\end{array}$} & \multicolumn{2}{|c|}{ 1st summer } & \multicolumn{2}{|c|}{ 2nd summer } & \multirow[b]{2}{*}{ SEM } \\
\hline & DG & CG & DG & CG & \\
\hline \multicolumn{6}{|l|}{ Proportion of fibres (\%) } \\
\hline Type SO* & 23.0 & 27.6 & 27.6 & 26.4 & 3.3 \\
\hline Type FOG* & 19.6 & 16.9 & 16.6 & 19.1 & 2.5 \\
\hline Type FG* & 57.4 & 55.5 & 55.8 & 54.5 & 5.1 \\
\hline \multicolumn{6}{|c|}{ Enzyme activities $\left(\mu\right.$ mole $\left.\cdot \min ^{-1} \cdot g^{-1}\right)$} \\
\hline \multirow[t]{2}{*}{$\mathrm{ICDH}^{* *}$} & 1164 & 1130 & 1218 & 1150 & 55 \\
\hline & 2.96 & 3.21 & 2.27 & 3.01 & 0.30 \\
\hline $\begin{array}{l}\text { Total collagen content } \\
\left(\mu \mathrm{g} \mathrm{OH}-\mathrm{prol} \cdot \mathrm{mg} \mathrm{DM}^{-1}\right)\end{array}$ & $4.97^{\mathrm{ab}}$ & $6.37^{\mathrm{a}}$ & $3.54^{\mathrm{b}}$ & $3.23^{\mathrm{b}}$ & 0.72 \\
\hline
\end{tabular}

The values are lsmeans \pm SEM (standard error of the mean). Lsmeans with different superscripts are significantly different: ${ }^{\mathrm{a}, \mathrm{b}}: P<0.05$.

* SO = slow oxidative; FOG = fast oxidoglycolytic; FG = fast glycolytic

** $\mathrm{LDH}=$ lactate dehydrogenase; ICDH = isocitrate dehydrogenase. 


\subsubsection{Feed intake and intake capacity}

Feed intake increases with the size of the animals, but their fatness depresses intake [12]. In this study, the values of SDMI decreased significantly between the first summer and the end of the experiment for animals in CG. Even if their diet was changed for good quality hay, the DG heifers did not show a significant increase of SDMI during the last year of the experiment. Intake capacity, which depends only on animal status, can help to illustrate this. A non linear equation, using FBW and BCS (minus central value of 2.5), was fitted on the IC of animals of both groups. Expressed in $\mathrm{FU}$, the result is as follows:

$$
\mathrm{IC}=0.017 . \mathrm{FBW}^{1.017}-0.564 .(\mathrm{BCS}-2.5)
$$$$
\mathrm{S}_{\mathrm{xy}}=1.450
$$

Using the t-test and asymptotic standard error of the estimate, the exponent associated with FBW has been shown not to differ significantly from 1 . This indicates that IC varies in relation with rumen size, more with FBW than with $\mathrm{FBW}^{0.75}$. Using the same test, the coefficient associated with $\mathrm{BCS}$ has been recognised to differ significantly from $0(P<0.01)$. This indicates that BCS acts significantly on IC. The determination coefficient $\left(\mathrm{R}^{2}\right)$ of this equation, calculated by the square of the correlation coefficient between observed and predicted, was estimated as 0.653 . This relatively low $\mathrm{R}^{2}$ underlines the difficulty in making simple statements about the relationships between feed intake, body weight and fatness, as stated by Forbes [12].

\subsubsection{Muscle characteristics}

With increasing age, the mean fibre area of TB muscle increased and the total collagen content decreased between 22 and 34 months of age. The change in mean fibre area was not accompanied by changes in the proportions of different fibre types or in LDH and ICDH activities. Similar results were described by Grenet et al. [15] for
Semitendinosus muscle of Limousin heifers between 28 and 40 months of age. Confirming these data, other unpublished results from our laboratory showed that ICDHactivity in both Semitendinosus and TB muscles did not change between 24 and 36 months of age in Limousin heifers, but then increased significantly between 36 and 43 months. In males, several publications on animals from 1 to 16 months of age [3, $23,24,32$ ] and from 1 to 24 months of age in several breeds [42] have shown a more oxidative muscle metabolism at 12 months of age. The present results suggest that muscle metabolism becomes more oxidative with age later in females than in males. The decrease of collagen content between the first and the second summer can be explained almost entirely by the proportion of adipose tissue, which increased significantly during the second summer in particular. So as dry matter increased, total collagen content (in $\mu \mathrm{g}$ OH-prol per mg DM) decreased. Similar results have been reported by Grenet et al. [15] for Semitendinosus muscle of Limousin heifers.

\subsection{Nutritionally induced growth paths}

\subsubsection{Weight}

The results show evidence of compensatory growth by discontinuously growing heifers. Animals compensate for a part of the weight difference that is realised during winter periods with continuously growing heifers. Complete compensation has often been observed for sheep, more rarely for cattle [18]. In order to characterise the intensity of the compensation, a compensation index has been built. This index represents the percentage of the weight difference between CG and DG at the end of the restriction period that is caught up after the compensation period [43]. In this study, the compensation index was 56.4 and $47.8 \%$ at the end of the first and the second year of the experiment respectively. These values 
correspond to the low limit of what is usually observed [19].

\subsubsection{Feed intake}

The group was not shown to have a significant effect on SDMI, over the two years of the experiment. However, reducing the analysis to the first year of the experiment showed that the interaction between group and period significantly influenced SDMI. More particularly, summer values differed significantly between CG and DG (t test, $P<$ 0.05). During the first summer, standardised feed intake of discontinuously growing animals was about $6.5 \%$ higher than that of continuously growing heifers (cf. Tab. III). Similar values have been reported by Micol and Béranger [30]. During the second summer, fatness of the animals depressed $\mathrm{CG}$ and DG intake (cf. above) and prevented from distinguishing SDMI of both groups.

\subsubsection{Body and gain composition}

Low quality feeding affected adipose tissues more than the muscles in discontinuously growing heifers. As for non-carcass tissues, different responses were observed, depending on the organ under consideration. For example, unlike the digestive tract, the weight of the liver decreased during periods of restriction. Ryan et al. [41] measured a decrease in the liver as well as in the digestive tract of sheep and cattle. However, unlike in this study, their animals were subjected to a restriction of intake. As far as chemical composition is concerned, the protein component of non-carcass tissues was more sensitive to the low quality feed than carcass proteins.

No major difference was finally observed between the two groups for the tissue or for the chemical composition of the animals slaughtered at the same final live weight, as already observed [41, 44].

As is well recognised [35], the gain is all the richer in lipids when the average daily weight gain is high. This explains the alter- nation of lipid-poor and lipid-rich gain phases for discontinuously growing heifers. During summer periods, the composition of the gain of these animals was identified as proportionally richer in lipids, compared with the gain of continuously growing heifers estimated over one year. These results do not support the hypothesis of a gain richer in protein for discontinuously growing beef cattle during compensation. However, it must be remembered that the intervals between measurements were of considerable duration. Furthermore, the chosen type of animal (hardy breed heifers) contributes to obtaining fat animals at the final slaughter.

For an identical weight gain difference between the two groups for both winter periods, the difference in the average daily net energy intake tended to be higher during the second winter period. This is explained by a higher lipid content in the gain with growth [38], and therefore higher energy requirements to realise the same gain difference as heifers grow. The comparison of the total net energy intake between the two groups illustrates the better efficiency in energy utilisation of animals undergoing compensatory growth, since discontinuously growing animals needed less energy to reach the same chemical composition. Nevertheless, this observation has to be tempered on account of the small and slightly significant measured difference in energy intake and because of the small number of animals involved. This apparent higher energy utilisation, already measured by Carstens et al. [6], associated with an increase of intake, are two major mechanisms explaining compensatory growth.

\subsubsection{Hormonal status}

Bovine thyroidal status is known to play a major role in growth and development and to be affected by energy availability [8]. These authors have shown that feed restriction decreased thyroidal secretion rather than extrathyroidal T3 synthesis in growing steers. Here, concentration of T3 (metabolically active) was sharply decreased by feed 
restriction of growing heifers during both winters. Conversely, T4 concentration was unaltered. This result is surprising since circulating T4 is suspected to be more closely associated with energy consumption than circulating T3 [17]. This may suggest that, in the present experiment, feed restriction induced by low quality forage may have primarily decreased extrathyroidal T3 synthesis rather than thyroidal secretions. As previously observed [8], T3 concentrations were restored to control levels during the summer in DG heifers. However, the T3 concentration did not rise above that of control heifers in contrast to our previous data in steers [8].

\subsubsection{Muscle characteristics}

In this study, the TB muscle was chosen because it was particularly responsive to altered energy supply [4]. We observed no significant differences between the two groups of heifers on contractile and metabolic properties of TB at the end of the two summers (refeeding periods). Data from the literature show a decrease in muscle fibre areas after a restriction period (for review: [18]) which may be explained mainly by a decrease in accumulation of nuclei and protein [34]. From our results, we can hypothesise that muscle fibre mean area was restored during the refeeding period and was not significantly different between DG and $\mathrm{CG}$ groups at the end of the summers. The fact that contractile and metabolic properties of TB were not different between the two groups at the end of summers is consistent with similar levels of thyroid hormones (T3 and T4) in both groups. These hormones control the expression of myosin heavy chain (MHC) genes [5, 7, 26]. Thyroid hormone also plays an important role in the control of mitochondrial metabolism (for review: [7]). In a previous study [8], it was shown that after energetic restriction followed by compensatory growth, circulating T3 concentration rose above that of steers growing continuously. This may have been responsible for differences mainly in metabolic oxidative properties and in hybrid fibre occurrence in the TB muscle [9]. Our present data are also consistent with those of Maltin et al. [29] concluding that the manipulation of feeding level has only a small effect on muscle fibre characteristics. Total collagen content too did not differ between the two groups at the end of the summers. Some studies demonstrate a neosynthesis of collagen during compensatory growth [10, 11, 25]. Others describe a decrease in the toughness of connective tissue after compensatory growth $[2,16]$. In our study, the level of restriction and compensation induced by differences in hay quality would not have been sufficient to induce neosynthesis of collagen. A high inter-muscular variability of the effects of feeding level on collagen properties has been widely described in the literature (for review: [18]). This shows that our result on one muscle cannot be generalised for all muscle types.

In conclusion, feeding animals a low quality diet during winter periods did not hamper growth very much over the entire experimental period. Physiological adaptations to low quality feed, modifications of hormonal status for instance, enabled the animals to compensate when a good quality diet was subsequently given. Even though compensation was not complete, the delay in the slaughter date was small and body composition was not affected. Furthermore, continuous or discontinuous growth induced by the quality of hay fed in the winter resulted in the same contractile and metabolic properties of the muscle. The results of this study support the practice of adapting growth path to the availability of food and to its quality.

\section{ACKNOWLEDGEMENTS}

The authors received a financial grant from the French government (FNADT). The authors would like to thank M. Petit and M. Vermorel for critical discussion of the experimental design, the staff of the experimental farm in Marcenat, the Theix slaughter house and the laboratory for measurements and technical assistance. 


\section{REFERENCES}

[1] Agabriel J., Giraud J.M., Petit M., Détermination et utilisation de la note d'état d'engraissement en élevage allaitant, Bull. Tech. CRZV Theix 66 (1986) 43-50.

[2] Allingham P.G., Harper G.S. Hunter R.A., Effect of growth path on the tenderness of the semitendinosus muscle of Brahman-cross steers, Meat Sci. 48 (1998) 65-73.

[3] Brandstetter A.M., Picard B., Geay Y., Muscle fibre characteristics in four muscles of growing bulls. I. Postnatal differentiation, Livest. Prod. Sci. 53 (1998) 15-23.

[4] Brandstetter A.M., Picard B., Geay Y., Muscle fibre characteristics in four muscles of growing male bulls. II. Effect of castration and feeding level, Livest. Prod. Sci. 53 (1998) 2526.

[5] Butler-Browne G.S., Barbet J.P., Thornell L.E., Myosin heavy and light chain expression during human skeletal muscle development and precocious muscle maturation induced by thyroid hormone, Anat. Embryol. 181 (1990) 513-522.

[6] Carstens G.E., Johnson D.E., Ellenberger M.A., Tatum J.D., Physical and chemical components of the empty body during compensatory growth in beef steers, J. Anim. Sci. 69 (1991) 3251-3264.

[7] Cassar-Malek I., Listrat A., Picard B., Contrôle hormonal des caractéristiques des fibres musculaires après la naissance, INRA Prod. Anim. 11 (1998) 34-45.

[8] Cassar-Malek I., Kahl S., Jurie C., Picard B., Influence of feeding level during post-weaning growth on circulating concentrations of thyroid hormones and extrathyroidal 5'-deiodination in steers, J. Anim. Sci. 79 (2001) 2679-2687.

[9] Cassar-Malek I., Jurie C., Listrat A., Jailler R., Bauchart D., Kahl S., Picard B., Hocquette J.-F., Adaptations spécifiques au mode de conduite de différents types de muscles chez les bovins, Viandes Produits Carnés (hors série) (2002) 133-134.

[10] Crouse J.D., Cross H.R., Seideman S.C., Effect of sex condition, genotype, diet, and carcass electrical stimulation on the collagen content and palability of two bovine muscles, J. Anim. Sci. 60 (1985) 1228-1234.

[11] Damergi C., Picard B., Geay Y., Robins S.P., Effets de la modulation de la croissance entre 9 et 16 mois sur les caractéristiques du collagène intramusculaire chez le bovin, in: Flamant
J.C., Gabiña D., Espejo Díaz M. (Eds.), Proceedings of the International Symposium on basis of the quality of typical Mediterranean animal products, 1998 , pp. $465-470$.

[12] Forbes J.M., Voluntary food intake and diet selection in farm animals, CAB International, Wallingford, UK, 1995.

[13] Geay Y., Micol D., Robelin J., Berge P., Malterre C., Recommandations alimentaires pour les bovins en croissance et à l'engrais, Bull. Tech. CRZV Theix 70 (1987) 173-183.

[14] Geay Y., Bauchart D., Hocquette J.F., Culioli J., Effect of nutritional factors on biochemical, structural and metabolic characteristics of muscles in ruminants, consequences on dietetic value and sensorial qualities of meat, Reprod. Nutr. Dev. 41 (2001) 1-26.

[15] Grenet N., Mourier C., Geay Y., Jurie C., Picard B., Colin G., Durand Y., Le Pichon D., L'illusoire tri physiologique des génisses, Viandes Produits Carnés 21 (2000) 173-179.

[16] Harper G.S., Allingham P.G., LeFeuvre R.P., Changes in connective tissue of M. semitendinosus as a response to different growth paths in steers, Meat Sci. 53 (1999) 107-114.

[17] Hayden J.M., Williams J.E., Collier R.J., Plasma growth hormone, insulin-like growth factor, insulin, and thyroid hormone association with body protein and fat accretion in steers undergoing compensatory gain after dietary energy restriction, J. Anim. Sci. 71 (1993) 3327-3338

[18] Hoch T., Begon C., Cassar-Malek I., Picard B., Savary-Auzeloux I., Mécanismes et conséquences de la croissance compensatrice chez les ruminants, INRA Prod. Anim. 16 (2003) 49-59.

[19] Hornick J.L., Van Eenaeme C., Gerard O., Dufrasne I., Istasse L., Mechanisms of reduced and compensatory growth, Domest. Anim. Endocrin. 19 (2000) 121-132.

[20] INRA (Institut National de la Recherche Agronomique), Alimentation des ruminants, INRA Publications, Versailles, 1978.

[21] INRA (Institut National de la Recherche Agronomique), in: Jarrige R. (Ed.), Ruminant nutrition: recommended allowances and feed tables, John Libey, Eurotext, Montrouge, France, 1989.

[22] Jarrige R., Demarquilly C., Dulphy J.P., Hoden A., Robelin J., Béranger C., Geay Y., Journet M., Malterre C., Micol D., Petit M., The INRA « fill unit » system for predicting the voluntary intake of forage-based diets in 
ruminants: a review, J. Anim. Sci. 63 (1986) 1737-1758.

[23] Jurie C., Robelin J., Picard B., Renand G., Geay Y., Postnatal changes in the biological characteristics of Semitendinosus muscle in male Limousin cattle, Meat Sci. 41 (1995) 125-135.

[24] Jurie C., Picard B., Geay Y., Changes in the metabolic and contractile characteristics of muscle in male cattle between 10 and 16 months of age, Histochem. J. 31 (1999) 117122.

[25] Kopp J., Bonnet M., Le tissu conjonctif musculaire, Bull. Tech. CRZV Theix 48 (1982) 34-37.

[26] Larsson L., Muller U., Li X., Schiaffino S., Thyroid hormone regulation of myosin heavy chain isoform composition in young and old rats, with special reference to IIX myosin, Acta Physiol. Scand. 153 (1995) 109-116.

[27] Listrat A., Rakadjiyski N., Jurie C., Picard B., Touraille C., Geay Y., Effect of the diet on muscle characteristics and meat palatability of growing Salers bulls, Meat Sci. 53 (1999) 115-124.

[28] Littell R.C., Henry P.R., Ammerman C.B., Statistical analysis of repeated measures data using SAS procedures, J. Anim. Sci. 76 (1998) 1216-1231.

[29] Maltin C.A., Lobley G.E., Grant C.M., Miller L.A., Kyle D.J., Horgan G.W., Matthews K.R., Sinclair K.D., Factors influencing beef eating quality 2 . Effects of nutritional regimen and genotype on muscle fibre characteristics, Anim. Sci. 72 (2001) 279-287.

[30] Micol D., Béranger C., Variations de la capacité d'ingestion de bovins en croissance et à l'engrais, Bull. Tech. CRZV Theix 44 (1981) 23-31.

[31] O'Donovan P.B., Compensatory gain in cattle and sheep, Nutr. Abstracts Rev. B 54 (1984) 389-410.

[32] Ouali A., La maturation des viandes : facteurs biologiques et technologiques de variation, Viandes Produits Carnés 11 (1990) 281-290.

[33] Peter J.B., Barnard R.J., Edgerton V.R., Gillepsie C.A., Stempel K.E., Metabolic profiles of three fiber types of skeletal muscle in guinea pigs and rabbits, Biochemistry 11 (1972) 2627-2633.

[34] Rehfeldt C., Stickland N.C., Fiedler I., Wegner J., Environmental and genetic factors as sources of variation in skeletal muscle fibre number, Basic Appl. Myol. 9 (1999) 237-255.

[35] Robelin J., Influence de la vitesse de croissance sur la composition du gain de poids des bovins : variations selon le génotype et le sexe, Ann. Zootech. 28 (1979) 209-218.

[36] Robelin J., Agabriel J., Estimation de l'état d'engraissement des bovins vivants à partir de la taille des cellules adipeuses, Bull. Tech. CRZV Theix 66 (1986) 37-41.

[37] Robelin J., Geay Y., Estimation de la composition chimique du corps entier des bovins à partir du poids des dépôts adipeux totaux, Ann. Zootech. 27 (1978) 159-167.

[38] Robelin J., Daenicke R., Variations of net requirements for cattle growth with liveweight, liveweight gain, breed and sex, Ann. Zootech. 29 (1980) 99-118.

[39] Robert-Granié C., Heude B., Foulley J.L., Modelling the growth curve of Maine-Anjou beef cattle using heteroskedastic random coefficients models, Genet. Sel. Evol. 34 (2002) 423-445.

[40] Ryan W.J., Compensatory growth in cattle and sheep, Nutr. Abstracts Rev. B 60 (1990) 653-664.

[41] Ryan W.J., Williams I.H., Moir R.J., Compensatory growth in sheep and cattle II Changes in body composition and tissue weights, Aust. J. Agr. Res. 44 (1993) 16231633

[42] Wegner J., Albrecht E., Fiedler I., Teuscher F., Papstein H.-J., Ender K., Growth- and breed-related changes of muscle fiber characteristics in cattle, J. Anim. Sci. 78 (2000) 1485-1496.

[43] Wilson P.N., Osbourn D.F., Compensatory growth after undernutrition in mammals and birds, Biol. Rev. 35 (1960) 324-363.

[44] Yambayamba E.S.K., Price M.A., Jones S.D.M., Compensatory growth of carcass tissues and visceral organs in beef heifers, Livest. Prod. Sci. 46 (1996) 19-32. 